\title{
ARMOUR RESEARCH FOUNDATION OF IUINOIS INSTITUTE OF TECHNOLOGY
}

TECHNOLOGY CENTER. 10 WEST BSTH STREET. CHICAGO 16, ILLINOIS. CAIUMET S-9GOO

November 28, 1962

ARF-B238-4

United States Atomic Energy Commission

Metallurgy and Materials Programs

Division of Research

Washington 25, D. C.

Attention: Dr. W. F. Sheely

Gentlemen:

Subject: $\quad$ Report No. ARF-B238-4 on Contract No.

AT (11-1)-578, Project Agreement No. 19

"Alloying Characteristics of the Rare Earth

Elements with the Transition Elements"

This is report ARF-B238-4 summarizing the technical progress on the subject contract for the period September 15 to November 14, 1962.

The alloying characteristics of the rare earth elements with the transition metals undergo a radical change in nature as the atomic numbe $r$ of the transition series increases--transition elements in Groups IV a, $\mathrm{V} a$, and VI a are immiscible with the rare earths, while elements of Groups VII $a$, and VIII $a$, VIII $b$, and VIII $c$ form many compounds. A reasonable explanation for this behavior is a valency or electronegativity effect. Those binary systems forming compounds form "Laves Phases," which can exist in one of three related crystal structures. The specific Laves type crystal structure can be related to the average free electron concentration. This phenomenon has been used previously to calculate electronic valency of other systems. From a thorough compilation of the known Laves-type phases occurring between rare earth elements and transition metals, the crystal structure trend supports the hypothes is that the valency effect is indeed operative; however, further substantiation of these trends is necessary. In the present program, uninvestigated rare earth--transition metal binary systems are being surveyed to establish the existence or non-existence of the Laves type phase, and to classify the crystal structure of observed Laves phases. Alloying between Laves phases of unlike crystal structure will then be made to establish solubility limits from which valencies will be calculated. 


\section{DISCLAIMER}

This report was prepared as an account of work sponsored by an agency of the United States Government. Neither the United States Government nor any agency Thereof, nor any of their employees, makes any warranty, express or implied, or assumes any legal liability or responsibility for the accuracy, completeness, or usefulness of any information, apparatus, product, or process disclosed, or represents that its use would not infringe privately owned rights. Reference herein to any specific commercial product, process, or service by trade name, trademark, manufacturer, or otherwise does not necessarily constitute or imply its endorsement, recommendation, or favoring by the United States Government or any agency thereof. The views and opinions of authors expressed herein do not necessarily state or reflect those of the United States Government or any agency thereof. 


\section{DISCLAIMER}

Portions of this document may be illegible in electronic image products. Images are produced from the best available original document. 
Experimental Progress

During the past work period, the following alloys have been arc melted and their crystal structure tentatively identified:

$\begin{array}{ll}\mathrm{TbOs}_{2} & \mathrm{MgNi}_{2} \text { or } \mathrm{MgZn}_{2} \\ \mathrm{HoOs}_{2} & \mathrm{MgNi}_{2} \text { or } \mathrm{MgZn}_{2} \\ \mathrm{LuRe}_{2} & \mathrm{MgNi}_{2} \text { or } \mathrm{MgZn}_{2} \\ \text { ErOs }_{2} & \mathrm{MgNi}_{2} \text { or } \mathrm{MgZn}_{2} \\ \text { DyOs }_{2} & \mathrm{MgNi}_{2} \text { or } \mathrm{MgZn}_{2}\end{array}$

Lattice parameters have been determined for the following:

$\begin{array}{ll}\operatorname{TbPt}_{2} & a=7.167 \mathrm{~A} \\ \text { HoPt }_{2} & a=7.590 \\ \text { LuFe }_{2} & a=7.216 \\ \text { LuNi }_{2} & a=7.065 \\ \operatorname{DyPt}_{2} & a=7.602 \\ \operatorname{DyIr}_{2} & a=7.517 \\ \text { LuIr }_{2} & a=7.453\end{array}$

Difficulties have been experienced in attempts to prepare compounds in which there is a great difference in the melting points of the components. Liquid state sintering, arc melting, and levitation melting, or combinations of these processes, have either been tried or are currently under way. The following compounds fall into this category:

$\begin{array}{ll}\mathrm{YbW}_{2} & \text { DyW }_{2} \\ \mathrm{YbOs}_{2} & \mathrm{HoW}_{2} \\ \mathrm{YbRh}_{2} & \text { HoRe }_{2} \\ \mathrm{YbRu}_{2} & \mathrm{YbFe}_{2} \\ \mathrm{SmRe}_{2} & \mathrm{YbMn}_{2} \\ & \text { DyRe }_{2}\end{array}$

The investigation of the structure of ternary alloys between known Laves phases of different crystal structures has been initiated during the past work period. The initial work is concentrated on the rare earthfirst transition series alloys. Compositions are prepared at intervals of 20 atomic per cent. Four intermediate compositions of each of the following ternary systems have been prepared: 


$$
\begin{aligned}
& (\mathrm{Er}+\mathrm{Ho}) \mathrm{Mn}_{2} \\
& (\mathrm{Dy}+\mathrm{Er}) \mathrm{Mn}_{2} \\
& (\mathrm{Ho}+\mathrm{Tm}) \mathrm{Mn}_{2} \\
& (\mathrm{Dy}+\mathrm{Tm}) \mathrm{Mn}_{2} \\
& \mathrm{Er}(\mathrm{Mn}+\mathrm{Fe})_{2} \\
& \operatorname{Tm}(\mathrm{Mn}+\mathrm{Fe})_{2}
\end{aligned}
$$

Future Work

The melting and identification of both binary and ternary alloys will continue during the coming work period. The development of two IBM 7090 programs to determine precision parameters and to calculate intensities will be initiated.

Respectfully submitted,

ARMOUR RESEARCH FOUNDATION OF ILLINOIS INSTITUTE OF TECHNOLOGY

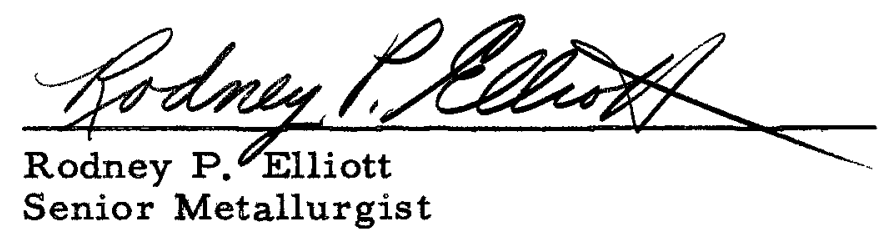

Tech. Rev. - RJV

cc: Mr. Richard Radd

Chicago Operations Office

U.S. Atomic Energy Commission

Argonne, Illinois 